\title{
Will the Future EU-UK Free Trade Agreement Affect Foreign Direct Investment?
}

This article aims to provide new insight on how Brexit will affect foreign direct investment (FDI) into the UK. By estimating an augmented gravity equation which accounts for the depth of free trade agreements (FTAs) as well as for EU and euro area membership, the article gauges the potential impact that different EU-UK trade scenarios might have on FDI flows and stocks. Results show that under a no-deal scenario, FDI flows from the EU into the UK would plunge by $25.9 \%-40.6 \%$, and inward FDI stocks would decrease by $49.2 \%-53.9 \%$. However, the depth of the future FTA can mitigate this negative outcome. More generally, the article shows that the FDI costs of leaving the EU would be significantly higher for the euro area countries.

Extensive research has highlighted the benefits from the European Union (EU) and the Economic and Monetary Union in terms of trade and foreign direct investment (FDI). The acquis communautaire, common currency and the free movement of goods, services, people and capital appear to have reduced transaction costs and fostered the development of economic activities by multinational enterprises (e.g. Carril-Caccia and Pavlova, 2018; Coeurdacier et al., 2009; De Sousa and Lochard, 2011; Martínez-San Román et al., 2016; Umber et al., 2014).

There has been a great deal of Euroscepticism in the last few years despite the fact that the EU project seems to have delivered relevant economic benefits to its member states. In the UK, this scepticism resulted in the Brexit vote on 23 June 2016. More than three years later, after significant political convulsion and uncertainty, the UK has left the EU. This year, the EU and the UK will negotiate the future trade deal that will condition the future relations between both parties. The economic consequences of Brexit will depend on this deal (Dhingra et al., 2017). While the British government seeks a trade deal similar to the one that the EU signed with Canada (CETA), the EU is after a more comprehensive one (Adler, 2020, March 2).

(c) The Author(s) 2020. Open Access: This article is distributed under the terms of the Creative Commons Attribution 4.0 International License (https://creativecommons.org/licenses/by/4.0/).

Open Access funding provided by ZBW - Leibniz Information Centre for Economics.

* This work was supported by Generalitat Valenciana [GV/2017/052]; Junta de Andalucía [SEJ 340].

Federico Carril-Caccia, University of Deusto; and University of Granada, Spain.
Most of the available analysis agrees on the negative consequences that Brexit could have on trade, FDI and welfare (e.g. Bailey et al., 2019; Bruno et al., 2016; Dhingra et al., 2017; Driffield and Karoglou, 2019; Greenaway and Milner, 2019; Mulabdic et al., 2017; Simionescu, 2018). In fact, the uncertainty brought about by the Brexit announcement appears to have already negatively impacted the UK's financial market stability and trade (e.g. Belke et al., 2018; Douch et al., 2018; Korus and Celebi, 2019).

Dhingra et al. (2017) point out that in the hard Brexit scenario, in which no free trade agreement (FTA) is signed and the UK and the EU trade under the World Trade Organization (WTO) rules, British income per capita would plunge by $9.4 \%$. Dhingra et al. (2017) highlight that not only trade but also the potential drop in FDI might be responsible for this outcome. In this case, research highlights the positive effect of FDI on economic growth or productivity in developed countries (e.g. Alfaro et al., 2004; Ashraf et al., 2015).

Theoretically, there are four main channels through which trade may affect inward FDI. First, with horizontal FDI, FDI and bilateral trade are substitutes. Multinational enterprises (MNEs) follow this strategy to serve the foreign market and to avoid trade costs (Horstmann and Markusen, 1987). If this MNEs investment strategy is predominant in the UK, the future new trade barriers between the EU and the UK will foster bilateral FDI.

Second, vertical FDI is positively associated with bilateral trade liberalisation. In this type of investment, MNEs establish production networks across borders that are linked through trade (Hanson, 2005). 
Third, export supporting FDI is also positively moderated by bilateral trade liberalisation. It refers to the investments that seek to enhance the market penetration from exports in a host country (Krautheim, 2013).

Fourth, MNEs may also create export platform subsidiaries in a country with the objective of serving third countries' markets through exports (Ekholm et al., 2007).

Through these FDI strategies, MNEs set subsidiaries to perform specific economic activities and link through trade, and in doing so, configure their global value chains (e.g. Amendolagine et al., 2017; Beugelsdijk et al., 2009; Krugman et al., 1995). If these MNEs' investment strategies are predominant, new barriers to trade brought by Brexit will hamper inward FDI into the UK. In this regard, Bailey et al. (2019) describe the potential negative consequences that Brexit might have on the automotive sector. More generally, Carril-Caccia and Pavlova (2020) show how global value chains participation and the capacity of exporting to (and importing from) a wider number of countries has a positive impact on the capacity of attracting cross-border mergers and acquisitions.

This article presents a study on how the depth of FTAs affects bilateral FDI, a topic rarely considered by previous literature. Indeed, FTAs have been extensively included as a determinant of FDI (e.g. Carril-Caccia and Pavlova, 2020; Garret, 2016; Hyun and Kim, 2010; Jang, 2011; Paniagua and Sapena, 2014), but FTAs are often assumed to be homogeneous by only considering whether a pair of countries have signed one or not. Nevertheless, countries sign FTAs with varying numbers of provisions that cover different policy areas like anti-dumping, competition, tariffs, intellectual property rights or data protection. In this way, the depth of FTAs is determined by their coverage in terms of policy areas.

Based on the relationship between FDI and the depth of bilateral trade integration, this work also extends the literature, which gauges the consequences of Brexit on FDI (e.g. Bruno et al., 2016). In particular, it sheds new light on the potential consequences that Brexit might have on FDI in different EU-UK trade agreements scenarios, and more generally disentangles the effect of leaving the EU for those countries that belong to the euro area (EA) and those that do not. Three different scenarios are considered: WTO rules (no FTA), an agreement similar to that between the EU and the European Free Trade Association (EFTA) and an agreement like the EU-South Korea FTA. ${ }^{1}$

\footnotetext{
1 Ideally we would like to include in the analysis the CETA-EU agreement, but the signature of this agreement is too recent (2019) to be available in the data used in the present article.
}

The results are in line with the literature that indicates the complementarity of FDI and trade and adds to the depth of the FTA as a relevant dimension when considering the FDI-FTA relationship. Furthermore, this article illustrates how the future FTA between the EU and the UK may affect bilateral FDI. If no FTA is signed, the UK could face a $25.9 \%-40.6 \%$ plunge in terms of FDI flows from the remaining EU members. Alternatively, if an FTA like the EU's with South Korea is signed, the drop would be between $13.3 \%$ and $22 \%$. In case an agreement is signed like the one between the EU and the EFTA, FDI into the UK would fall by between $4.2 \%$ and $7.2 \%$. Estimates for FDI stocks corroborate these findings, showing that in the best-case scenario (i.e. an EFTA-like agreement is signed), EU FDI stock in the UK would decline by $9.2 \%-10.5 \%$.

\section{Data and methodology}

The data sources are the OECD bilateral FDI flow and stock BMD3 and BMD4 data, World Bank's FTA database, World Bank's Development Indicators, and UNCTAD's International Investment Agreements database. The World Bank's FTA database covers 279 agreements signed by 189 countries between 1958 and 2015. The database includes not only the date of FTA signature but also their content; it provides each agreement coverage in terms of provisions that target distinct policy areas (see Hofmann et al., 2017).

The analysis covers the 68 host and source countries ${ }^{2}$ during the period $1985-2015 .{ }^{3}$ As proposed by Silva and Tenreyro (2006), we use the Poisson pseudo-maximum likelihood to estimate the following gravity equation:

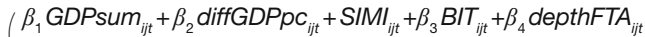

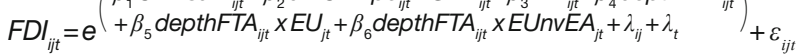

2 The FDI statistics cover the complete bilateral relationships between 36 economies, and the inward (or outward) investment from these 36 countries from (to) 32 other countries. Countries in the sample include (full bilateral FDI data available for countries in italics): Albania, Argentina, Australia, Austria, Belgium, Bosnia and Herzegovina, Brazil, Bulgaria, Canada, Chile, China, Colombia, Croatia, Cyprus, the Czech Republic, Denmark, Egypt, Estonia, Finland, France, Germany, Greece, Hong Kong, Hungary, Iceland, India, Indonesia, Iran, Ireland, Israel, Italy, Japan, Kuwait, Latvia, Lithuania, Luxembourg, Macedonia, Malaysia, Malta, Mexico, the Netherlands, New Zealand, Nigeria, Norway, Pakistan, Peru, the Philippines, Poland, Portugal, Romania, Russia, Saudi Arabia, Serbia, Singapore, Slovakia, Slovenia, South Africa, South Korea, Spain, Sweden, Switzerland, Thailand, Turkey, Ukraine, the United Arab Emirates, the United Kingdom, the United States, Venezuela.

3 In order to be able to cover the period 1985-2015 and the FDI to and from non-OECD countries, the BMD3 and BMD4 inward and outward FDI statistics are combined. Although there are slight differences in the used methodology for measuring investment between both series, during the period they overlap, (BMD3 and BMD4 statistics have a correlation of 0.86 ). 
in which FDI is the investment flow from country $i$ to country $j$ in year $t$. GDPsum $i j t$ is the combined economic size of the source and host country, diffGDPpc $c_{i j t}$ is the difference in GDP per capita between both countries, and $S I M I_{i j t}$ represents the economic size similarity between country $i$ and country $j$ in $t .{ }^{4} B I T_{i j t}$ is a dummy variable that takes the value 1 whenever a pair of countries have signed a bilateral investment treaty (BIT). Country pair fixed effects $\left(\lambda_{i j}\right)$ are included in order to avoid the potential endogeneity between bilateral investment and the likelihood of signing an FTA or BIT (Baier et al., 2008; Bergstrand and Egger, 2013). Furthermore, country pair fixed effects account for the multilateral resistance, that is to say, the relative attractiveness of countries to FDI (Anderson and van Wincoop, 2003). The year fixed effects $\left(\lambda_{t}\right)$ control for the world's macroeconomic trends.

Finally, as in Mulabdic et al. (2017), depthFTA $A_{i j t}$ is the number of provisions included in the FTA signed between country $i$ and $j$ in year $t$ divided by the maximum number of provisions of the deepest FTA in our sample. depthFTA $A_{i j t}$ is interacted with a dummy variable that takes the value 1 when a country becomes an EU member $\left(E U_{j t}\right)$ and by a dummy that represents those countries that become EU members but do not belong to the EA yet $\left(E U n v E A_{j t}\right)$. The objective of these interactions is respectively to quantify how the depth of the FTA affected the EU member states inward FDI and see whether the impact is different for those that did not adopt the euro. The significance of the sum of coefficients is tested with:

$$
t=\frac{\left(\beta_{r}+\beta_{k}\right)}{\sqrt{\sigma_{r}^{2}+\sigma_{k}^{2}-2 \times \operatorname{Cov}\left(\beta_{r}, \beta_{k}\right)}} ; r, k=4,5,6 .
$$

\section{Different potential future FTA scenarios}

The EU membership implies signing an FTA consisting of 42 provisions that include not only trade in goods, but also trade in services and dimensions such as intellectual property rights, competition policy and environment or capital movement. Post-Brexit FTA scenarios include EU-UK trade under the WTO rules (no FTA is signed), an agreement similar to the EU-South Korea FTA (which includes 22 provisions) and an agreement like EFTA (which includes 36 provisions). These hypothetical scenarios range from the most benign to the most trade-restrictive future trade relations, with numerous intermediate situations possible from trading under the WTO rules to the EU membership (see for instance Lydgate and Winters, 2018).

\footnotetext{
4 As in Jang (2011).
}

Table 1

FDI and FTA depth

\begin{tabular}{|c|c|c|c|c|c|c|}
\hline & & FDI flow & & & FDI stock & \\
\hline & (1) & (2) & (3) & (4) & (5) & (6) \\
\hline $\begin{array}{l}\text { GDPsum }_{i j t} \\
\left(\beta_{1}\right)\end{array}$ & $\begin{array}{l}1.392^{\star \star \star} \\
(0.17)\end{array}$ & $\begin{array}{l}1.439^{\star \star \star} \\
(0.17)\end{array}$ & $\begin{array}{l}1.442^{* * \star} \\
(0.17)\end{array}$ & $\begin{array}{l}0.928^{\star \star \star} \\
(0.19)\end{array}$ & $\begin{array}{l}1.069^{\star * \star} \\
(0.19)\end{array}$ & $\begin{array}{l}1.077^{* \star \star} \\
(0.18)\end{array}$ \\
\hline $\begin{array}{l}\text { diffGDPpc } \\
\left(\beta_{2}\right)\end{array}$ & $\begin{array}{l}0.478^{\star *} \\
(0.19)\end{array}$ & $\begin{array}{l}0.510^{\star \star \star} \\
(0.19)\end{array}$ & $\begin{array}{l}0.483^{\star \star} \\
(0.20)\end{array}$ & $\begin{array}{l}0.598^{\star \star \star} \\
(0.21)\end{array}$ & $\begin{array}{l}0.708^{\star \star \star} \\
(0.21)\end{array}$ & $\begin{array}{l}0.702^{\star \star \star} \\
(0.21)\end{array}$ \\
\hline $\operatorname{SIMI}_{i j t}\left(\beta_{3}\right)$ & $\begin{array}{l}0.243 \\
(0.27)\end{array}$ & $\begin{array}{l}0.254 \\
(0.27)\end{array}$ & $\begin{array}{l}0.235 \\
(0.27)\end{array}$ & $\begin{array}{l}0.214 \\
(0.32)\end{array}$ & $\begin{array}{l}0.224 \\
(0.32)\end{array}$ & $\begin{array}{l}0.213 \\
(0.31)\end{array}$ \\
\hline$B I T_{i j t}\left(\beta_{4}\right)$ & $\begin{array}{l}0.233 \\
(0.17)\end{array}$ & $\begin{array}{l}0.275^{\star} \\
(0.17)\end{array}$ & $\begin{array}{l}0.278^{*} \\
(0.17)\end{array}$ & $\begin{array}{l}0.049 \\
(0.16)\end{array}$ & $\begin{array}{l}0.140 \\
(0.17)\end{array}$ & $\begin{array}{l}0.142 \\
(0.17)\end{array}$ \\
\hline $\begin{array}{l}\text { depthFTA } \\
\left(\beta_{5}\right)\end{array}$ & $\begin{array}{l}0.321^{\star \star \star} \\
(0.12)\end{array}$ & $\begin{array}{l}0.061 \\
(0.18)\end{array}$ & $\begin{array}{l}0.068 \\
(0.18)\end{array}$ & $\begin{array}{l}0.256^{\star *} \\
(0.13)\end{array}$ & $\begin{array}{r}-0.285 \\
(0.18)\end{array}$ & $\begin{array}{l}-0.282 \\
(0.18)\end{array}$ \\
\hline $\begin{array}{l}\text { depthFTA } \\
E_{j i t} \times \\
U_{j t}\left(\beta_{6}\right)\end{array}$ & & $\begin{array}{l}0.460^{* \star *} \\
(0.18)\end{array}$ & $\begin{array}{l}0.811^{\star * \star} \\
(0.23)\end{array}$ & & $\begin{array}{l}1.059^{\star * *} \\
(0.20)\end{array}$ & $\begin{array}{l}1.225^{\star \star *} \\
(0.30)\end{array}$ \\
\hline $\begin{array}{l}\operatorname{depthFTA}_{i j t} \times \\
\operatorname{EUnvEA}_{j t}\left(\beta_{7}\right)\end{array}$ & & & $\begin{array}{c}-0.579^{* * *} \\
(0.22)\end{array}$ & & & $\begin{array}{l}-0.265 \\
(0.25)\end{array}$ \\
\hline $\begin{array}{l}\text { Fixed } \\
\text { effects }\end{array}$ & & & $\lambda_{i j}$ & & & \\
\hline Observations & 50684 & 50684 & 50684 & 44925 & 44925 & 44925 \\
\hline$R^{2}$ & 0.501 & 0.502 & 0.502 & 0.789 & 0.793 & 0.793 \\
\hline
\end{tabular}

Notes: Robust standard errors in parenthesis. Estimation method: PPML with country pair and year fixed effects. ${ }^{* *} p<0.01,{ }^{* *} p<0.05,{ }^{*} p<0.1$.

Source: Author's own calculations.

\section{Results: FDI and FTA depth}

Table 1 shows the regression result. Columns 1-3 refer to bilateral FDI flows and columns 4-6 refer to stocks. In line with previous research, FDI flows and stocks are positively moderated by the combined economic size from the home and host country (GDPsum ${ }_{i j t}$ ) and go from capitalabundant to labour-abundant countries. In addition, signing a BIT appears to boost bilateral FDI flows, but is insignificant in the case of stocks. ${ }^{5}$ Furthermore, in both cases, economic size similarity $\left(S I M I_{i j t}\right)$ is insignificant.

Column 1 shows that the depth of FTAs has an overall positive impact on bilateral FDI flows. According to the estimate of $\beta_{4}$, the deepest signed FTA in our sample (the EU with 42 provisions) would have increased bilateral FDI flows by $38 \% .{ }^{6}$ Alternatively, a shallower FTA like the one between the EU and South Korea, which has 22 provisions, results in only a $20 \%$ higher FDI.

5 The resulting lack of significance of BIT is not surprising. The literature highlights that the sign and significance associated with BIT is prone to depends on the sector of investment, the level of development of the signing countries or the existing intensity of bilateral FDI (e.g. Berger et al., 2011; Colen et al., 2011; Paniagua et al., 2015).

6 The effect from the depth of FTA are calculated by $e^{\beta_{4}} \times \frac{\text { No. of privisions in the FTA }}{42}-1$, with 42 being the number of provisions of the deepest FTA in our sample. 
Table 2

FDI flows scenarios

\begin{tabular}{lcccc} 
Scenarios & $\begin{array}{c}\text { No provi- } \\
\text { sions }\end{array}$ & $\begin{array}{c}\text { Leaving } \\
\text { the EU }\end{array}$ & $\begin{array}{c}\text { Leaving the } \\
\text { EU if the } \\
\text { country is } \\
\text { non-EA }\end{array}$ & $\begin{array}{c}\text { Leaving the } \\
\text { EU if the } \\
\text { country is EA }\end{array}$ \\
\hline EFTA & 36 & $-7.2 \%$ & $-4.2 \%$ & $-11.8 \%$ \\
\hline South Korea & 22 & $-22.0 \%$ & $-13.3 \%$ & $-34.2 \%$ \\
\hline WTO (no FTA) & 0 & $-40.6 \%$ & $-25.9 \%$ & $-58.5 \%$ \\
\hline
\end{tabular}

Notes: The shock of the EFTA and South Korea scenarios are calculated following Mulabdic et al. (2017). For example, on average for the EU, $E F T A=e((0.061+0.460) \times 36 / 42) / e((0.061+0.460) \times 42 / 42)-1=-0.072$.

Source: Author's own calculations based on estimates in columns 2 and 3 from Table 1.

In column 2 , the positive significance of $\beta_{6}$ suggests that in comparison with the rest of the world, the depth of FTAs is particularly relevant in explaining FDI into the EU. According to this estimate, joining the EU has increased FDI flows from its member states by $68 \%\left(e^{\hat{\beta}_{5}+\hat{\beta}_{6}}-1\right)$.

In line with the literature that highlights the benefits from the euro (Coeurdacier et al., 2009; De Sousa and Lochard, 2011), $\beta_{7}$ from depthFTA ijt $\times E U n v E A_{j t}$ is significant and negative. This indicates that the gains on FDI from the depth of the FTA are lower for those countries that have not adopted the euro yet. Accordingly, euro area member countries have seen an increase in FDI flows from other member states of $141 \%\left(e \hat{\beta}_{5}+\hat{\beta}_{6}-1\right)$, while the figure for

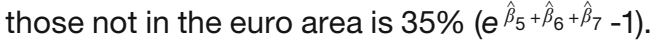

Estimates of the depth of FTAs on FDI stocks are in line with the findings for FDI flows. The FDI stock estimates represent the long-term effects of FTAs. Overall, the EU membership increased the FDI stock among its members by $116.8 \%$. The increase amounts to $156.8 \%$ for countries that adopted the euro and $97 \%$ for those that did not.

\section{The consequences of leaving the EU}

Based on the estimates from columns 2 and 3, for FDI flows, Table 2 approximates the consequences of leaving the EU under different FTA scenarios. On average, under a no-FTA scenario, a country that leaves the EU could expect a $40 \%$ drop in FDI flows from the remaining members, the fall being higher if it adopted the euro (58\%) than if it did not (26\%).

7 In line with Bruno et al. (2016), it is assumed that leaving the EU would have the same impact as joining it.
Table 3

FDI stocks scenarios

\begin{tabular}{lcccc} 
Scenarios & $\begin{array}{c}\text { No provi- } \\
\text { sions }\end{array}$ & $\begin{array}{c}\text { Leaving } \\
\text { the EU }\end{array}$ & $\begin{array}{c}\text { Leaving the } \\
\text { EU if the } \\
\text { country is } \\
\text { non-EA }\end{array}$ & $\begin{array}{c}\text { Leaving the } \\
\text { EU if the } \\
\text { country is } \\
\text { EA }\end{array}$ \\
\hline EFTA & 36 & $-10.5 \%$ & $-9.2 \%$ & $-12.6 \%$ \\
\hline South Korea & 22 & $-30.8 \%$ & $-27.6 \%$ & $-36.2 \%$ \\
\hline WTO (no FTA) & 0 & $-53.9 \%$ & $-49.2 \%$ & $-61.1 \%$ \\
\hline
\end{tabular}

Notes: The shock of the EFTA and South Korea scenarios are calculated following Mulabdic et al. (2017). For example, on average for the EU, $\left.\left.E F T A=e^{((-0.285+1.059)} \times 36 / 42\right) / e^{((-0.285+1.059)} \times 42 / 42\right)-1=-0.105$.

Source: Author's own calculations based on estimates in columns 5 and 6 from Table 1.

It is likely that the impact of Brexit on FDI into the UK will be closer to the average expected impact of those countries that never adopted the euro. Nonetheless, the UK has been an EU member for 40 years and it is one of the world's main FDI stockholders. Thus, the average impact of leaving the EU is considered to be the upper bound.

The negative impact of Brexit on FDI flows could be significantly lower if an FTA is signed. If an agreement is reached like the one between EFTA and the EU, the drop would be of only $4 \%-7 \%$. Instead, if a shallower FTA is signed, like the one between the EU and South Korea, the decrease in FDI would be between $13 \%$ and $22 \%$.

Table 3 reports the different scenarios for the case of FDI stocks. Leaving the EU will have sizable effects on the stock of FDI from the remaining member states in the UK. Even if the future EU-UK trade agreement is EFTA-like, the investment stock from the remaining states is likely to fall by between $9.2 \%$ and $10.5 \%$. If the WTO scenario is reached, the FDI stock in the UK from the remaining EU members is likely to be reduced by half.

\section{Conclusions}

Today, the future of the EU-UK relations is uncertain. The EU hopes to sign a more comprehensive FTA than the one that the British government seeks, and a no-deal scenario, in which both parties trade under WTO rules, is not fully unlikely. This article quantifies the consequences that different EU-UK FTA agreements could have on bilateral FDI.

Results show that there is a complementary relationship between bilateral FDI and trade liberalisation. Consequently, findings suggest that the new trade barriers be- 
tween the EU and the UK will reduce the EU's FDI in the UK. This negative effect may be caused by the disruption that Brexit will cause on MNEs' existing global value chains and their decision to set new ones.

The depth of the future FTA can significantly moderate the negative shock of Brexit on FDI. In the most benign scenario, the UK would be facing between a $4.2 \%$ and $7.2 \%$ drop in FDI flows from the remaining members. If the UK leaves the EU and no FTA is signed, the EU's FDI into the UK would significantly drop. In the long run, the UK's inward FDI stock from the EU member states is likely to reduce by half. Given that EU member states' FDI stock in the UK is currently nearly $45 \%$ of the total inward FDI stock in the country, this would translate into the total FDI stock in the UK plunging by $22.5 \%$.

More generally, this work highlights the relevance of accounting for the depth of FTA for explaining FDI. According to our results, signing a deep FTA may have sizable benefits on a country's inward FDI. But this analysis is only a first step. Future studies should identify the relevance of the different provisions that an FTA might have when explaining FDI.

\section{References}

Adler, K. (2020, 2 March), Brexit: What to expect from UK-EU trade talks, BBC, https://www.bbc.com/news/world-europe-51657084 (6 March 2020).

Alfaro, L., A. Chanda, S. Kalemli-Ozca, and S. Sayek (2004), FDI and economic growth: the role of local financial markets, Journal of International Economics, 64(1), 89-112.

Amendolagine, V., A. Presbitero, R. Rabellotti, M. Sanfilippo and A. Seric (2017), FDI, global value chains, and local sourcing in developing countries, IMF Working Papers, 17/284, https://www.imf.org/ /media/ Files/Publications/WP/2017/wp17284.ashx (18 June 2020).

Anderson, J. E. and E. Van Wincoop (2003), Gravity with gravitas: a solution to the border puzzle, American Economic Review, 93(1), 170-192.

Ashraf, A., D. Herzer and P. Nunnenkamp (2016), The effects of Greenfield FDI and cross-border M\&As on total factor productivity, The World Economy, 39(11), 1728-1755.

Baier, S. L., J. H. Bergstrand, P. Egger and P. A. McLaughlin (2008), Do economic integration agreements actually work? Issues in understanding the causes and consequences of the growth of regionalism, The World Economy, 31(4), 46-497.

Bailey, D., N. Driffield and E. Kispeter (2019), Brexit, foreign investment and employment: some implications for industrial policy?, Contemporary Social Science, 1-15.

Belke, A., I. Dubova and T. Osowski (2018), Policy uncertainty and international financial markets: the case of Brexit, Applied Economics, 50(34-35), 3752-3770

Berger A., M. Busse, P. Nunnenkamp and M. Roy (2011), More stringent BITs, less ambiguous effects on FDI? Not a bit!, Economics Letters, 112(3), 270-272.

Bergstrand, J. H. and P. Egger (2013), What Determines BITs?, Journal of International Economics, 90(1), 107-122.

Beugelsdijk, S., T. Pedersen and B. Petersen (2009), Is there a trend towards global value chain specialization? An examination of cross border sales of US foreign affiliates, Journal of International Management, 15(2), 126-141.

Bruno, R., N. Campos, S. Estrin and M. Tian (2016), Gravitating towards Europe: an econometric analysis of the FDI effects of EU membership, CEP technical paper.
Carril-Caccia, F. and E. Pavlova (2018), Foreign direct investment and its drivers: a global and EU perspective, ECB Economic Bulletin, 4/2018.

Carril-Caccia, F. and E. Pavlova (2020), Mergers and acquisitions \& trade: A global value chain analysis, The World Economy, 43(3), 586-614.

Coeurdacier, N., R. A. De Santis and A. Aviat (2009), Cross-border mergers and acquisitions and European integration, Economic Policy, 24(57), 56-106.

Colen, L., D. Persyn and A. Guariso (2016), Bilateral investment treaties and FDI: Does the sector matter?, World Development, 83, 193-206.

De Sousa, J. and J. Lochard (2011), Does the single currency affect foreign direct investment?, The Scandinavian Journal of Economics, 113(3), 553-578.

Dhingra, S., H. Huang, G. Ottaviano, J. Paulo Pessoa, T. Sampson and J. Van Reenen (2017), The costs and benefits of leaving the EU: trade effects, Economic Policy, 32(92), 651-705.

Douch, M., T. H. Edwards and C. Soegaard (2018), The trade effects of the Brexit announcement shock, Warwick Economics Research Papers, 1176.

Driffield, N. and M. Karoglou (2019), Brexit and foreign investment in the UK, Journal of the Royal Statistical Society: Series A (Statistics in Society), 182(2), 559-582.

Ekholm, K., R. Forslid and J. R. Markusen (2007), Export-platform foreign direct investment, Journal of the European Economic Association, 5(4), 776-795.

Garrett, J. Z. (2016), Explaining asymmetries in bilateral FDI flows, International Review of Economics \& Finance, 41, 155-171.

Greenaway, D. and C. Milner (2019), The economic impact of Brexit on the UK economy, The World Economy, 42(2), 2-4.

Hanson, G. H., Jr R. J. Mataloni and M. Slaughter (2005), Vertical production networks in multinational firms, Review of Economics and Statistics, 87(4), 664-678.

Hofmann, C., A. Osnago and M. Ruta (2017), Horizontal depth: a new database on the content of preferential trade agreements, World Bank Policy Research Working Paper, 7981.

Horstmann, I. J. and J. R. Markusen (1987), Strategic investments and the development of multinationals, International Economic Review, 28(1), 109-121.

Hyun, H. J. and H. H. Kim (2010), The determinants of cross-border M\&As: the role of institutions and financial development in the gravity model, The World Economy, 33(2), 292-310.

Jang, Y. J. (2011), The impact of bilateral free trade agreements on bilateral foreign direct investment among developed countries, The World Economy, 34(9), 1628-1651.

Korus, A. and K. Celebi (2019), The impact of Brexit news on British pound exchange rates, International Economics and Economic Policy, 16(1), 161-192.

Krautheim, S. (2013), Export-supporting FDI, Canadian Journal of Economics/Revue canadienne d'économique, 46(4), 1571-1605.

Krugman, P., R. N. Cooper and T. N. Srinivasan (1995), Growing world trade: causes and consequence, Brookings papers on economic activity, 1995(1), 327-377.

Lydgate, E. and L. A. Winters (2018), Deep and Not Comprehensive? What the WTO Rules Permit for a UK-EU FTA, World Trade Review, $1-29$.

Martínez-San Román, V., M. Bengoa and B. Sánchez-Robles (2016), Foreign direct investment, trade integration and the home bias: evidence from the European Union, Empirical Economics, 50(1), 197-229.

Mulabdic, A., A. Osnago and M. Ruta (2017), Deep integration and UKEU trade relations, World Bank Policy Research Working Paper Series, 7947.

Paniagua, J. and J. Sapena (2014), Is FDI doing good? A golden rule for FDI ethics, Journal of Business Research, 67(5), 807-812.

Paniagua, J., E. Figueiredo and J. Sapena (2015), Quantile regression for the FDI gravity equation, Journal of Business Research, 68(7), 15121518.

Silva, J. S. and S. Tenreyro (2006), The log of gravity, The Review of Economics and Statistics, 88(4), 641-658.

Simionescu, M. (2018), The impact of Brexit on the UK inwards FDI, Economics, Management and Sustainability, 3(1), 6-20.

Umber, M. P., M. H. Grote and R. Frey (2014), Same as it ever was? Europe's national borders and the market for corporate control, Journal of International Money and Finance, 40, 109-127. 